\title{
Hvor queer \\ var Baudrillard?
}

Af Jonatan Leer

En komparativ analyse af konskritik og alternative konsstrategier $i$ Jean Baudrillards De la séduction (1979) og Judith Butlers Gender Trouble (1990) moderne kønsklassiker Gender Trouble (1990) har været en af de mest afgørende bøger i de sidste tyve års kønsforskning. Samtidig har den været den mest kontroversielle. I bogen, der blev grundlæggende for queerteorien, ${ }^{1}$ proklamerede Butler, at der ikke var nogen biologisk eller psykologisk essens, der kunne retfærdiggøre dikotomien mand/kvinde. Disse kategorier var 'komplekse kulturelle konstruktioner'. Således blev den franske feminist Simone de Beauvoirs (1908 -1986) parole "Man fødes ikke kvinde, man bliver det" presset til det yderste, da Butler foreslog at opfatte kønnet som 'performance', der blev styret af sociale regulerende instanser.

Butler har aldrig lagt skjul på, at hun skylder den franske filosof Michel Foucaults konstruktivistiske og genealogiske analyser meget. Derimod nævnes den franske postmodernistiske filosof Jean Baudrillard (1929-2007) ikke med et eneste ord i hele bogen. Det er bemærkelsesværdigt, da han 
11 år før Butler skrev bogen De la séduction (1979). Den giver på mange måder udtryk for en lignende kønsopfattelse, og selve begrebet 'performance' har en del tilfælles med et af Baudrillards vigtigste begreber, nemlig 'simulation'.

Der mangler en klar analyse af forholdet mellem Baudrillards postmodernistiske kønsopfattelse og queerteoriens måde at koncipere kønnene på. I denne artikel vil jeg ud fra de nævnte værker forsøge at undersøge i hvor høj grad, man kan tænke disse to kønsopfattelser sammen. Endvidere vil jeg også prøve at sammenligne deres strategier for nye formuleringer af forholdet mellem krop, køn og identitet. Det er mit mål at vise, at queerteorien ikke er kommet ud af ingenting. Den er derimod et produkt af et større paradigmeskift inden for kunst og filosofi, som Baudrillard med sine radikale samtidsanalyser har været en vigtig del af. ${ }^{2}$ I artiklens første del vil jeg vise, hvordan både Baudrillard og Butler gør op med modernismens kønsforestilling ved at sammenligne deres kritik af kønnets repræsentation i feminismen og i psykoanalysen. ${ }^{3}$ Herefter følger en komparativ analyse af deres måder at nytænke kønnet på, der vil blive relativiseret gennem inddragelsen af Lillian Munk Rösings Konnets Katekismus (2005).

\section{FEMINISMEKRITIK}

Både Baudrillard og Butler gør i deres værker op med feminismen. ${ }^{4}$ De mener, at den har spillet fallit i forsøget på at frigøre kvinden. Det er nødvendigt at gøre radikalt op med den måde, som den fremstiller kønnet på for rigtigt at kunne komme videre $\mathrm{i}$ frigørelsesprocessen.

Allerede fra de forste sider af De la séduction går Baudrillard til angreb på feminismens måde at positionere sig som mandens modsætning:

Hvad er det kvinderne, i deres protestbevægelse, stiller i modsætning til den fallokrati- ske struktur? En autonomi, en forskel, en specificitet i begær og i nydelse, en anden brug af deres krop, en tale en skrift - aldrig forførelsen. (Baudrillard 1979/1997: 17).

Feministerne fokuserer altså for meget på det konkrete og det biologiske. De insisterer konstant på den kvindelige krop og det kvindelige begær som centrale punkter i deres oprør. Men ifølge Baudrillard er de nødt til at komme udover det reelle, 5 hvis der skal ske radikale ændringer. Baudrillard ser i forførelsen en mulighed for at etablere en falskhed i relationen til den anden og til magten. Det falske skal på ingen måde forstås som noget negativt. Det er blot det modsatte af det sande som det, der henviser til noget konkret (f.eks. kroppen eller kønnet som essens). Baudrillard mener, det er bedre at gå ind i et kunstigt spil med kønstegn - det han kalder 'faire jouer le corps' end at forsøge at finde en sandhed i kroppen, for der findes den i hvert fald ikke.

Men de fleste feminister anser, ligesom den østrigske psykoanalytiker Sigmund Freud (1856-1939), anatomien for at være skxbnen (Baudrillard 1979/1997: 20). Heriblandt er den franske feminist Luce Irigaray (f. 1932), der argumenterer for, at kvinden modsat manden har mulighed for en mere mangfoldig seksuel nydelse. Hun kan nemlig stimuleres på flere måder end manden, da hendes erogene zoner både er klitoris, bryster, vaginaen etc. Irigaray forsøger altså at frigøre den kvindelige seksualitet ved at fremhæve dens særlige egenskaber. Men for Baudrillard forbliver dette ræsonnement fastlåst $\mathrm{i}$ anatomien. Hermed afskrives forførelsen, som er det eneste, der "radikalt modsætter sig anatomien som skxbne". Ifølge Baudrillard forspilder feminister som Irigaray gennem denne insisteren på anatomien den chance, de havde for gennem forførelse at nedbryde den maskuline orden.

Med dette for øje mener jeg, at den amerikanske forsker A. Keith Goshorn har ret $\mathrm{i}$ at påpege $\mathrm{i}$ en artikel om Baudrillard 
og feminismen, at han ikke kritiserer kvinden, men feminismen som bevægelse (Goshorn 2000: 280-312). Baudrillard fremhæver netop 'det kvindelige' (dvs. forførelsen) og dets overlegenhed over for det mandlige. Men inden vi kommer nærmere ind på, hvad der præcist ligger i forførelsen, lad os se hvori Butlers feminismekritik består.

Selvom Judith Butler selv definerer sig som feminist, rummer Gender Trouble en skarp kritik af store dele af den moderne feminisme. Kritikken er særligt møntet på frygten for at beskrive kønnet på en mindre determineret og mere fri måde: "De moderne feminismedebatter om kønnets betydning bliver ofte problematiske, som om kønnenes ubestemmelighed eventuelt ville kulminere i feminismens fald." (Butler 1990/1999: xxix). Problematiseringen af kønnet, som så mange feminister frygter, mener Butler ikke, at man skal være så bange for. Den er nødvendig. Hun går så langt som til at sige, at feminismen går patriarkatets ærinde ved at opretholde den binære kønsforestilling. Den er nemlig dikteret af den patriarkalske orden. Når feminismen bruger den som referent, så indordner den sig under dens diskurs og dens dominans. At nedbryde kønnenes binaritet er at frigøre dem fra den 'heteroseksuelle matrice'. Denne matrice betegner den kulturelle forståelsesramme, der gør krop, køn og begær naturlige (Butler: 1990/1999: 208, Goshorn 2000: 280-312).

Kritikken fortsættes i bogens første afsnit "Woman" as the subject of feminism. Her klandres feminismen for at finde sin berettigelse i det faktum, at 'kvinden' er en konstant og naturlig identitet. Men hermed overses alle andre forhold som er identitetsskabende (f.eks. klasse, etnicitet, race): "hvis man er kvinde, er det vel ikke alt, man er." (Butler 1990/1999: 4). Ved kun at tænke kvinden som den biologiske kategori 'ikke-mand' står feminismen i vejen for den frihed, den kæmper for, da identitetsbegrebet begrænses til noget rent kønsligt.
Butler agiterer for en ny feminisme. Den skal slå tvivl om kategorierne køn og identitet. Således skulle omformuleringen af disse fundamentale kategorier både være dens metodiske og politiske mål (Butler 1990/ 1999: 7-8). Feminismens redning skal ifølge Butler paradoksalt nok findes i opløsningen af 'kvinden'.

Butler og Baudrillard er altså enige om, at feminismens strategi ikke er den rigtige. Der bliver fokuseret alt for meget på ensartethed i den kvindelige fysik. Næste fælles kritikpunkt er begæret, der ligeledes er en grundsten i den 'anatomiske fælde'.

\section{KRITIK AF BEGÆRET SOM KØNNENES SPECIFICITET OG ESSENS}

I moderniteten har begæret været et vigtigt parameter til at beskrive kønnenes specificitet. Psykoanalysen har i den forbindelse spillet en stor rolle. For Freud er identitetsdannelse nemlig forbundet med barnets erkendelse i overgang til voksenlivet af dets seksuelle objekt og af dets begær. ${ }^{7}$ Denne proces er særlig svær for pigebarnet, da det dels skal komme ud over penismisundelsen og skifte erogen zone fra klitoris til vagina, dels skal nedbryde moderbindingen og forstå, at dets seksuelle objekt er mænd (Laplanche/Pontalis 1967/2007: 230231).

Baudrillard kritiserer Freud for at fokusere for meget på begæret og for at mene, at begæret er sandheden. Det er en idé, som kvindebevægelserne har taget til sig, som vi så det i citatet tidligere. Ifølge Baudrillard har feminismen og psykoanalysen det tilfælles, at de begge insisterer på, at 'sandheden' er indskrevet i kroppen og i begæret (Baudrillard 1979/1997: 16-17). Men ifølge Baudrillard (og Butler) er kroppen blot en blank side, der tillægges mening gennem kulturelle læsninger. Der findes ingen sandhed om kroppen, da den blot afspejler kulturelle og ideologiske transformationer.

For Baudrillard eksisterer der i vores postmoderne virkelighed kun simulakra, 
dvs. kopier af kopier, der ikke længere kan spores tilbage til nogen form for original, og simulationer, der er kæder af simulakra (Baudrillard 1981: 10-17). Således er kroppen en foranderlig størrelse, der primært eksisterer gennem vores aktuelle virkelighedsopfattelse. Den postmoderne virkelighedsopfattelse er præget af pornografi, forbrugskultur og et mediebillede, der slører grænsen mellem virkelighed og fiktion. Men accepterer man, at alt er skin, så kan man gå ind i den 'leg', som 'virkeligheden' er, og blive en aktiv deltager. ${ }^{9}$

Det er her, forførelsen kommer ind i billedet. Den er netop en leg med tegn og betydning, der ikke tror på den dybe bagvedliggende mening. Således står forførelsen i modsætning til kroppen 'som skæbne'. Baudrillard kritiserer Freud for at have opgivet at forstå forførelsens centrale betydning for den menneskelige identitet. Han placerede i stedet for seksualiteten og begæret på essentielle pladser i sit menneskebillede:

Freud opgav også selv forførelsen og indførte i stedet en overordentlig operationel fortolkningsmekanisme, en i høj grad seksuel fortrængningsmekanik, der frembyder alle kendetegn på objektivitet og kohærens...

(Baudrillard 1979/1997: 64).

Freud udviklede ellers mellem 1895 - 97 en forførelsesteori, som gik ud på at tidlige oplevelser af forførelse, hvor barnet passivt bliver forført, spiller en vigtig rolle i personlighedsudviklingen. Teorien opgives efter få år. Dette ses som et afgørende skift både $\mathrm{i}$ Freuds tænkning og i udviklingen af psykoanalysen (Laplanche/Pontalis 1967/ 2007: 437). Da Freud i 1897 går væk fra forførelsesfantasmet, begynder han nemlig at forklare den menneskelige psyke gennem mere kropsrelative metaforer: penismisundelse, oral fase, anal fase etc. Baudrillard mener, at Freud gennem dette skift går fra en abstrakt og fascinerende tænkning til en mere konkret og forfladigende tænkning.
Freud omfavner hermed den strukturelle orden. Den står i modsætning til forførelsens orden, der er mere kompliceret, mere flydende og som derfor passer bedre til Baudrillards måde at beskrive mennesket på (Baudrillard 1979/1997: 63-66).

Butlers begærskritik er på mange måder lig Baudrillards, men hendes er direkte møntet på den heteroseksuelle matrice. For Butler er vores samfund og den måde, vi tænker kønnene på, i høj grad domineret af heteroseksuelle normer og værdier. Dette heteroseksuelle tyranni hævder dets 'naturlighed' med henvisning til, at denne seksuelle praksis fører til reproduktion. I denne kontekst ses den heteroseksuelle (køns)identitet som den eneste legitime, og valoriseringen af det heteroseksuelle begær forbliver helt centralt for at skabe dette binære og stabile kønsmønster:

Institutionaliseringen af en obligatorisk og naturlig heteroseksualitet kræver, at kønnene tilpasses i et binært forhold, hvor det mandlige skelnes fra det kvindelige. Denne skelnen fuldbyrdes gennem udøvelsen af det heteroseksuelle begær. (Butler 1990/1999: 31).

Således bliver det heteroseksuelle begær en afgørende faktor for identitetsdannelse i den heteroseksuelle matrice. Butler påpeger, at det betyder, at der er en række identiteter, der bliver 'umulige', da de ikke kan italesættes inden for den heteroseksuelle diskurs, f.eks. transseksuelle og homoseksuelle.

Tesen udbygges med et ret ekstremt eksempel: Herculine Barbin - en hermafrodit fra det nittende århundrede. Han/hun levede først som kvinde, men under et besøg hos en læge, blev tvekønnetheden bemærket. Mange smertefulde undersøgelser senere blev det fastslået at hans/hendes køn var maskulint. Foucault har udgivet hans / hendes dagbog, samt de medicinske journaler. ${ }^{10}$ Dette vidnesbyrd udstiller ifølge Butler, hvordan den konventionelle heteroseksuelle verdensopfattelse ikke kan inklu- 
dere sådan et subjekt som Herculine, da han/hun er en seksuel og sproglig umulighed (Butler 1990/1999: 32). Den heteroseksuelle matrice opererer gennem sproget og kan ikke beskrive fænomener, der ikke inkarnerer det heteroseksuelle begær. Sproget er konstituerende for begærsopfattelsen i matricen. Når hovedkonklusionen i Gender Trouble bliver, at man ikke kan opretholde distinktionen 'gender', det kulturelle køn, og 'sex', det biologiske køn, så er det fordi, at 'sex' også er sprogligt konstitueret.

Butler mener ikke, at den heteroseksuelle matrice kun findes i vores almindelige hverdagssprogbrug, men den har også været herskende inden for en række videnskabelige diskurser. Særligt fremhæves psykoanalysen og den strukturalistiske antropologi, som vi møder den hos franskmanden Claude Lévi-Strauss (f. 1908). Centrale begreber i hans analyser af 'primitive kulturer' var incestforbudet og ødipuskomplekset, begge termer er taget fra Freud. De forklares ikke, men de antages blot som 'kulturens universelle sandhed'. Butler problematiserer, at begæret, som det præsenteres her, beror på, at incestuøs heteroseksualitet er det mest naturlige i verden (Butler 1990/ 1999: 42).

\section{KØNNET SOM PERFORMANCE OG MATERIALISERING}

Den amerikanske sprogforsker John Langshaw Austin (1911 - 1960) er den første, der bruger begrebet performativer i bogen How To Do Things With Words fra 1962.11 I denne tekst interesserede han sig for de performative ytringer (f.eks. 'jeg døber dig', 'jeg sværger'). Det særlige ved disse ytringer er, at de udgør en handling i sig selv. ${ }^{12}$ I en sætning som 'jeg løber mig en tur' er sprogbrugeren nødt til at løbe en tur for at udføre handlingen, men i sætningen 'jeg erklærer Jer hermed for rette ægtefolk at være' indgås et xgteskab simultant med at udsagnet ytres. Derfor er sætningen i sig selv en handling. Blandt de mange, der har videreudviklet begrebet, er den franske filosof Jacques Derrida (1930-2005). Det er denne læsning, Butler overfører på kønsteorien. For Derrida er Austins fortjeneste, at han får sproget ud af dets 'logiske-semantiske fængsel', således at sproget kan opfattes som et instrument, der udgøres af rene sproglige akter uden den klassiske konstaterings referent (Derrida: 1971: 382). ${ }^{13}$ Han relativiserer dog Austins performativitetsteori og afviser, at den enkelte ytring kan være motiveret af et psykologisk 'jeg'. Den diskursive orden er selv en styrende faktor i den sproglige performance. ${ }^{14}$

Butler brugte begrebet i en kønsteoretisk sammenhæng af to årsager: dels fordi det understreger, at det kønnede er noget, der skabes uden for den enkelte, dels fordi performativitet ikke er en enkelt episode, men en repetition og et ritual, der forsøger at bruge kroppen til at legitimere og 'naturliggøre' en særlig kønsopfattelse.

Performance-begrebet er et opgør med metafysikkens ideal om, at der findes en skjult essens bagved det synlige køn. Kønnet er udelukkende en sammenstilling af en stribe fabrikerede kønstegn (gestik og begærsmarkører) (Butler 1990/1999: 185). Der er altså tale om et tegnspil på overfladen, der skal få kroppen til at skabe illusionen om en essentiel kønsidentitet. Butler opfatter den kønnede krops udtryk som primært performative. Derfor anses disse handlinger for ikke at have anden ontologisk status end den kønnede fiktion, de skaber. Kønnene er hverken sande eller falske. De eksisterer kun igennem deres verbalisering (Butler 1990/1999: 186). Det nye ved Butlers måde at tænke kønnet på er, at det ikke kan tænkes uden for kulturen - og når de er en del af kulturen, så er det performativt.

Butler understreger, at den måde, kønnene er performative på nu om dage, er styret af den heteroseksuelle matrice. Gentagelsen er et vigtigt element i køn-somperformance-ideen, da den sikrer stabilitet og kontinuitet i matricens kønsopfattelse. 
Der er i bund og grund tale om et socialt ritual, der legitimerer den heteroseksuelle kultur i repetition (Butler 1990/1999: 191).

Dog er det paradoksalt nok i gentagelsen, at der er en mulighed for at forårsage en forskydning i det binære kønssystem. Man kan ved at variere gentagelsen lave en parodi på det oprindelige køn. Derved bliver det muligt at destabilisere det institutionaliserede køn. Fænomener som 'drag', der er en tydelig 'performance', udstiller den måde kønnet er 'performeret' på inden for den heteroseksuelle matrice. Herved sættes der spørgsmålstegn ved forestillingen om kønnet som noget oprindeligt og naturligt.

Projektet fortsæettes i bogen Bodies that matter (1993). Her vil Butler prøve at definere forholdet mellem kroppens materialitet og performance. Butler accepterer, at kroppen indgår i en fysisk virkelighed, hvor den fødes, lever og dør. Men hun påpeger, at der er en problematisk zone mellem konstruktion og materialitet. Materien opfattes som regel som en ureducerbar essens. Men den kan ikke være betydningsbærende uden for kulturen, derfor kan man aldrig nå en krop i 'ren form'. Butler spiller på ordet 'matter', der blandt flere ting både kan betyde 'materie' og 'betyde'. Naturen er kun betydningsfuld, når den er kulturelt forståelig. 15 Derfor foreslår Butler at opfatte materien (og dermed kroppen og kønnet) som en materialisation (Butler 1993: 9), dvs. en inkarnation af kønnet på kroppens overflade, der opretholder ideen om kønnet som en stabil dikotomisk størrelse. Spørgsmålet er så ikke længere om kønnet er konstrueret eller ej, men målet er nærmere at undersøge gennem hvilke mekanismer, kroppens materialitet konstrueres? Og hvordan bliver kroppen kulturelt forståelig? (Butler 1993: xi-xii).

\section{KøNNET SOM FORTRYLLET OG} AFFORTRYLLET SIMULATION

Som nævnt i indledningen er Jean Baudril- lard ofte associeret med begreberne simulakrum og simulation. Simulakrum er populært sagt en kopi af en kopi, dvs. et tegn eller et billede, der ikke henviser til nogen virkelighed eller original. Som eksempel på simulakrum giver han 'trompe-l'oeil'-maleriet. Det prøver ikke at gengive virkeligheden, men nærmere at sætte spørgsmålstegn ved den og forvirre tilskueren:

I trompe l'oeil drejer det sig ikke om at smelte sammen med det reelle, det drejer sig om at producere et simulakrum i fuld bevidsthed om spillet og kunstgrebet [...] at så radikal tvivl om realitetsprincippet, idet man mimer og overdriver realitetseffekten. (Baudrillard 1979/1997: 70)

Det er Baudrillards påstand, at vi lever i et postmoderne samfund, hvor sådanne oplevelser af simulakrum og forvirring er konstante. Kommercialiseringen af samfundet og mediernes allestedsnærværelse gør, at vi ikke længere kan skelne det virkelige fra det uvirkelige. Denne opløsning af det reelle, kalder han for hyperrealitet. Baudrillard mener, at USA er det bedste eksempel på hyperrealiteten. Det er et land, der modsat Europa ikke afspejler en gammel kulturhistorie. Derimod er det baseret på en grundlæggende fiktion, der opløser grænserne mellem utopi, realitet og drøm. Hyperrealiteten er på en gang både skræmmende og fascinerende. ${ }^{16}$

Simulation er en kæde af simulakra. Inden for seksualiteten findes der to simulationer: pornografien og forførelsen. Pornografien er en affortryllet simulation. Dens close-up på kønnet ødelægger både den seksuelle fantasi og det rumlige perspektiv (Baudrillard 1979/1997: 37). Således levner den ingen plads til fantasien eller den erotiske leg. Det gør forførelsen derimod, der er en fortryllet simulation. Ligesom trompe-l'oeil-maleriet leger forførelsen med tegnene og sandheden. Den fordrejer forholdet mellem representation og virkelighed (Baudrillard 1979/1997: 60). 
For Baudrillard kan forskellen mellem porno og forførelse ses som en forskel mellem et produktionsprincip og et rstetisk princip: "At producere er med magt at materialisere noget, der tilhører en anden orden, nemlig hemmelighedens og forførelsens orden."(Baudrillard 1979/1997: 44). I et lidt større idéhistorisk perspektiv kan man sige, at Baudrillard modstiller den borgerlige og den aristokratiske orden. Det moderne samfund er baseret på produktion og forbrug. Dette samfund er det borgerlige, industrialiserede samfund, hvor selve produktionen og det nyttige har altafgørende værdi. Baudrillard savner det symbolske og det unyttige fra det aristokratiske samfund, hvor en rituel beskæftigelse som forførelse var vigtig. Forførelsen er helt det modsatte af produktionen. Den frembringer ikke andet end symbolik og ritualitet $\mathrm{i}$ legen med tegnene.

I sin læsning af den danske filosof Søren Kierkegaards (1813-1855) roman Forførerens dagbog (1843) viser Baudrillard, hvordan det traditionelle magtforhold ophæves i forførelsen. Der er ikke tale om et offer/ bøddel-forhold. Parterne udfører nærmere en dansende duel, hvor begge sætter deres identitet på spil. At forføre er at gøre skrøbelig, siger Baudrillard et sted i bogen. Denne lille sætning er helt central for at forstå det reversible forhold, der hersker i forførelsen. Jo mere den, der forføres, giver efter, jo skrøbeligere bliver dette 'offer'. Men når forføreren kaster sig ud i en forførelse, så opgiver han kontrollen og lægger sin skæbne i den andens hænder. Ingen af parterne i det forhold, der udgør forførelsens falske rum, har den absolutte magt. Den er reversibel: "Forførelsen sigter altid mod reversibiliteten og bortmaningen af en magt. Hvis forførelsen er kunstig, så har den også karakter af opofring." (Baudrillard 1979/1997: 93).

Reversibiliteten er også vigtig for at forstå kønsperspektivet i Baudrillards optik. Han opererer ikke med kategorierne mand og kvinde, men primært med det mandlige og det kvindelige. Det er dog ikke altid helt enkelt, da det er uklart hvilken rolle kroppen spiller i bogen. Der er ikke primært tale om to fysiske køn, men nærmere om to forskellige kræfter eller to former for magt. Den fallokratiske magt er en fasttømret magt, der er styret af libido og magtbegxr. Heroverfor har vi det kvindelige, der ikke er en modsætning til det mandlige, men den er blot andetsteds (ailleurs). Baudrillard definerer det kvindelige som det, der făr den fallokratiske struktur og dermed den binære logik til at bryde sammen (Baudrillard: 1979/1997: 14). Han taler om kønnene som noget, der er skabt af fallokratiet. Det kvindelige eller forførelsen kan opløse denne klassiske kønsstruktur. Det kvindelige og det mandlige kan opfattes som metaforer for to slags kønsøkonomier. Den mandlige deler kønnene op i dikotomier: mand/kvinde, stærk/svag. Den kvindelige nedbryder enhver form for modsætningsforhold og materiel stabilitet i kønnene. I bund og grund er denne opløsning det, der er på spil i forførelsen.

Baudrillard præsenterer i bogens første del, Kønnets forsvinden, to forskellige måder at gøre op med fallokratiets dominans på: dels gennem den seksuelle frigørelse, dels gennem forførelsen. I den seksuelle frigørelse kræver kvinderne at få deres plads i den fallokratiske struktur. De vil ind i libidoens orden og have anerkendt deres begær i en maskulin kontekst. Det kunne man kalde for en affortryllet revolution af kønnet - parallelt med pornografien som affortryllet simulation af erotikken. I forførelsen omgås fallokratiet og kønnene opløses på en fortryllet måde ved hele tiden at arbejde i vekselvirkning mellem den mandlige og den kvindelige pol.

Det, der affortryller kvindernes frigørelsesbevægelse, er, at de vil træde ind i den fallokratiske struktur. F.eks. ved at holde fast $\mathrm{i}$ at kvindekroppen afspejler et køn, der er det modsatte af manden. Distinktionen mellem mand og kvinde er indført af fallokratiet, og så længe feminismen bliver ved 
med at bruge det sprog og de termer, der er dikteret af fallokratiet, kan de ikke frigøre sig. Her har vi en klar parallel til Butler; hun kalder bare fallokratiet for den heteroseksuelle matrice. Frigørelsen fra den maskuline orden bør i stedet ske igennem forførelsens orden. Den sigter netop mod at få den maskuline magtforståelse til at bryde sammen.

Baudrillards forførelse skal forstås som meget mere end en erotisk leg. Den er en strategi, der kan bruges til at forpurre den klassiske magtrelation. En sådan magtrelation beror på fornuft, orden og klare modsætninger. Hvis man rykker ved én af disse byggesten, kan man fă hele konstruktionen til at kollapse.

\section{ER KØNNET DRAG ELLER DIALOG?}

Butler ser som nævnt i 'dragperformancen' en parodi på forestillingen om et oprindeligt køn og en illustration af, at køn altid er en performance. Kroppens overflade afspejler ikke nogen indre kerne. Baudrillard deler fascinationen af den tegnforvirring, som transvestismen spiller på. Der er nemlig ikke tale om nogen biseksuel eller homoseksuel aktivitet, men et signifikationsspil på kønnets overflade. Transvestismen sætter spørgsmålstegn ved køn som “determinerende og hemmelig instans" og “det, transvestitterne forelsker sig i, er netop dette spil med tegnene, de er lidenskabeligt optaget af at forfore selve tegnene." (Baudrillard 1979/1997: 20). Der sxttes de samme mekanismer på spil som i forførelsen, særligt vigtig er den ironiske strategi, der indfører et reversibelt forhold.

Det skræmmende perspektiv i denne kønsopfattelse er, at den implicerer en identitetsopfattelse, der reducerer subjektet til ren overflade. Man kunne indvende imod både Baudrillard og Butler, at de i deres ekstreme konstruktivisme kommer til at udviske enhver form for identitet. Hvad er der så tilbage?

I bogen Kønnets katekismus (2005) for- søger den danske feminist Lillian Munk Rösing (f. 1967) at lancere en slags kønnets dialogiske essentialisme. Hun foreslår, at mennesket har to eksistentialer: døden og dets køn. Problemet er ikke, at der findes to køn, for det kan vi ikke gøre noget ved. Opgaven er derimod at få dem til at gå i dialog og acceptere forskellene. Selvom konstruktivismen har været med til at afdække en stribe kulturelle klicheer, så er dekonstruktionen af kønnet som essens absurd og formålsløs. Derfor kritiseres konstruktivisterne for at ville afskaffe kønnet i deres kønsrevision. Rösing mener, at man "kan godt placere kønnet i kroppen uden nødvendigvis at betragte det som en essens (Rösing 2005: 72)." Hun foreslår, at man altså tænker kroppen mellem anatomi og fantasi.

Der er en klar psykoanalytisk vinkel i Rösings ræsonnement. Og man kunne spørge, om psykoanalysen ikke netop er en fantasi, der tager udgangspunkt i kroppen? Det ville Butler og Baudrillard nok mene. Konflikten opstår i vægtningen af forholdet mellem fantasi og anatomi. Hvis anatomien er det eneste udgangspunkt for fantasien, så ender man med ren Freud (jf. udtryk som penismisundelse, anal - oralfase etc.). Kritikken af psykoanalysens hos Butler og Baudrillard kører netop på, at den placerer sig mellem videnskab og fantasi, og bruger kroppen som mellemled og 'dokumentation' for dens postulater. Hvis man derimod anser anatomi for ren fiktion, sådan som vi ser det hos Butler og Baudrillard, kommer man nemt ud på et overdrev, hvor det bliver svært at indgå i etiske forhold til andre mennesker, da de ligesom en selv primært er materialiseringer af de dominerende diskurser.

Det er nok vigtigt at have den fornuft og pragmatisme med, som Rösing foreslår, når man beskxftiger sig med queerteori og postmodernistisk kønsteori. Der er dog meget interessante ting at hente hos disse teoretikere. Jeg mener, at en af deres helt store fortjenester er deres måde at gentæn- 
ke forholdet mellem kønnet og magten på. De postulerer, at når man giver slip på kønnet som stabilt referencepunkt og opløser det binære kønsperspektiv, så opløser man også det klassiske magtforhold. En fascinerende tanke, der synes at fordre en revurdering af kønnets placering $\mathrm{i}$ den politiske sfære. Ønsket om en nyfortolkning af magtbegrebet går igen hos flere postmodernister, som den danske kønsforsker Tania Ørum preciserer det i sin fremstilling af den postmodernistiske kønsopfattelse. Hun argumenterer for, at de fleste maskuline postmodernister netop ønsker at forlade den fallokratiske magtposition:

Ønsket om at forlade den traditionelle maskuline magtposition synes at være generelt for de mandlige postmoderne tænkere (således også Deleuze m.fl.). Den maskuline position har tilsyneladende lidt et almindeligt prestigetab, mistet sin legimitet... (Ørum/Svane: 1991: 22).

Ideen om at opløse den traditionelle magtopfattelse genfinder man i Butlers queerteori. 18

Med dette for øje mener jeg, man kan sige, at der eksisterer et dialogisk element hos Butler og Baudrillard - et forhold som Rösing synes at savne. De mener bare, at man er nødt til at frigøre kønnet fra de vante rammer for at komme videre. En af mulighederne er parodiens ironiske strategi. Humor gør det nemlig umuligt for magten at fortsætte sin dominans, den er nødt til at indgå i et reversibelt forhold, dermed bliver den mere skrøbelig. Et reversibelt forhold må vel siges at være en form for dialog. Den foregår bare på en mere gyngende grund.

\section{KONKLUSION}

Konkluderende vil jeg påpege, at der synes at være en klar parallel mellem den måde kønnene opfattes på hos Butler og Baudrillard: både i deres kritik af moderniteten (fe- minismen og psykoanalysen) og i deres afvisning af kroppen 'som skæbne'. Således er deres teorier et gennemført opgør med en entydig og stabil køns- og virkelighedsopfattelse. Endvidere findes hos begge en valorisering af den ironiske strategi, der kommer til udtryk gennem et opgør med den materialisme, der har styret moderniteten. Så selvom om Butler synes at insistere mere på heteroseksualitetens undertrykkende dimension end Baudrillard, så kommer kønsspørgsmålet hos begge til at betyde, at en rakke fundamentale begreber må gentænkes, så som magt, etik, revolution.

Det mest originale frellespunkt i Butler og Baudrillards kønsopfattelse er deres forståelse af relationen mellem magten og identiteten. De mener begge, at hvis man vil ændre kønsopfattelsen, så skal man skabe en dialog på andre præmisser end dem, der er skabt af magten og ikke være bange for at opgive en stabil identitet. Det er det, Butler påpeger, når hun hævder, at "dekonstruktionen af identiteten ikke er en dekonstruktion af det politiske" (Butler 1990/ 1999: 203). Det er blot en måde at gentænke politikken på. Baudrillard er inde på det samme i kapitlet om "angsten for at blive forført" (Baudrillard 1979/1997: 125136). Det, feministerne kan lære af ham, er at tænke deres oprør mod den maskuline dominans på en ny måde. Hvis magten skal opløses, skal det ske ud fra en reversibel platform. ${ }^{19}$

Jeg mener, at man kan gå endnu længere. Queerteorien er parallel til postmodernismens opfattelse af identitet, sådan som det fremstår i dens politiske og kunstneriske strategier fra 1980 og frem. Der gøres her op med det konstante i identitetsbegrebet gennem fragmentation, stilskift og intertekstualitet. Postmodernismen vil placere subjektet i nye relationer til de sociale instanser. Fornuft, lov og moral sættes ud af spil til fordel for xstetiske regler, ${ }^{20}$ som f.eks. da dogmebrødrene gennem deres manifest forsøgte at genfinde det legende element i den kreative proces ved at pådut- 
te sig selv nogle regler, der gik imod de gxldende normer. ${ }^{21}$ De gav således slip på deres vante instruktørrolle og blev nødt til at skabe en ny kunstnerisk identitet. I sådanne processer sker der en forskydning $\mathrm{i}$ subjektets forhold til andre sociale instanser, og der skabes en reversibilitet ud fra et typisk postmoderne koncept. Denne reversibilitet starter vel at mærke med, at instruktøren selv giver afkald på sin vanlige magtposition.

Analogt hertil kan man sige, at Butler og Baudrillard vil opfinde kønnet på ny ved at opløse dets rammer. De vil placere det i en ny social kontekst og $\mathrm{i}$ en ny relation til samfundets regulerende instanser. Det er her, vi finder den største parallel mellem queerteorien og postmodernismen. Spørgsmålet er måske ikke så meget, hvor queer var Baudrillard? men nærmere: var postmodernismen ikke en nødvendig forudsætning for queerteoriens opståen?

\section{Noter}

1. Dette er vel næppe stedet, man behøver introducere queerteorien, men jeg vil blot minde om, at begrebet queer theory ikke er opfundet af Judith Butler, men er tilskrevet den italiensk-amerikanske litterat Terese Lauretis, der brugte det første gang under en konference ved California University, Santa Cruz, i februar 1990 ifølge artiklen The Normalizing of Queer Theory, David Halperin, Journal of homosexuality, V 45, s. 339-343. Man kan finde en omfattende og ret underholdende introduktion til ordet queer og dets mange betydninger i den første franske bog om queerteori og litteratur af François Cusset: Queer critics - La littérature française déshabillée par ses homo-lecteurs (2002), se særligt Introduction: La gloire est trouée (7-18), Lectures perverses (19-36) og Pour ne pas conclure (191-197). Se endvidere Sexuality and Queer theory (Colebrook 2004: 206-239).

2. Baudrillard (1929-2007) har ikke været særlig velset i sit hjemland Frankrig, hvor han har været i opposition til de dominerende filosofiske kredse, hvilket nok skyldes hans frie, fragmenterede udtryk og de provokerende postulater (à la "Golfkrigen har ikke fundet sted", "Vi er alle transseksuelle",
“Holocaust er primært en tv-begivenhed"...). Derimod opnåede han kultstatus i USA, hvor han blev opfattet som "the supertheorist of a new postmodernity" (Best/Keller 1991: 111). Postmodernismen er introduceret i filosofien af den franske filosof Jean-François Lyotard (1924-1998) i bogen La condition postmoderne (1979). Heri defineres det postmoderne som "de store fortællingers død", hvilket betyder, at der i den postmoderne verden ikke længere eksisterer den occidentalske kulturs store fortællinger (f.eks. kristendommen), men heller ikke modernismens forsøg på at skabe nye fortællinger (marxismen og psykoanalysen) synes længere at have nogen værdi, da viden og filosofi i det postmoderne samfund er i konstant udvikling. Baudrillard giver næsten endnu stærkere end Lyotard udtryk for, at et opgør med moderniteten er nødvendigt, da den teknologiske udvikling i den grad præger vores postmoderne verdensbillede. Baudrillards tekster har ofte et litterært tilsnit, særligt Cool memoires I- $V$. Heri illustreres den postmoderne forvirring og usikkerhed gennem en fragmentarisk og springende skrivepraksis.

3. For både Butler og Baudrillard er modernismens kønsopfattelse karakteriseret ved at opfatte kroppen som en essens; enten ved at relatere til kønnet gennem psykoanalysens kropsopfattelse eller ved at tænke kønnet ind i marxismens materialisme eller ved at bruge kvindekroppen til at skabe en stabil og alternativ modpol til den fallokratiske orden. Claire Colbrooke kommer med en længere analyse af forholdet mellem modernitet og materialitet, der presenteres mere nuanceret end hos Baudrillard og Butler (jf. Colebrook 2004: 76-116).

4. Jeg har i denne artikel valgt at benytte termen feminisme i ental. Jeg er klar over, at dette kan forekomme lidt forsimplende, da feminismen har udviklet sig til en relativ heterogen gruppe, der rummer mange forskellige undergrupper fra essentialister til konstruktivister, fra pornografikritikere til prosex-bevægelsen. Disse er ofte så uenige om det feministiske projekt, at det eneste korrekte vil være at pluralisere begrebet og tale om feminismer. Når jeg har valgt at bruge begrebet i ental her, så er det fordi, både Butler og Baudrillard holder sig til ental, f.eks. Butler i bogens første kapitel "Woman” as the subject of feminism (Butler: 1990/1999: 2$8)$. Baudrillard anvender termen 'kvindebevægelsen' eller 'kvinderne' (Baudrillard: 1979/1997: 16-17). De opponerer begge imod den del af feminismen, der bruger kvindekroppen som stabil referent. Det er dog klart Butler, der giver den mest nuancerede fremstilling af feminismen, da hun inddrager flest forskellige sider af den: den radikale lesbiske feminisme hos Monique Wittig 
(1935-2002), den psykoanalytiske tilgang hos Julia Kristeva (f. 1941), den feministiske eksistentialisme hos Simone de Beauvoir (1908-1986) m.fl. Det bliver dog for omfattende at komme ind på alle disse her.

5. Når Baudrillard taler om det reelle, mener han den del af vores virkelighedsopfattelse, der er baseret på det konkrete og en moralsk forestilling om noget sandt. Som Mike Gane rigtigt skriver, anser Baudrillard dette for blot at være endnu en "affortryllet fiktion", der ikke er mere rigtig end nogen anden form for simuleret virkelighed: “...det reelle [for Baudrillard] er lig det rationelle, det sande og derfor blot en form for fiktion, en affortryllet form, som er en del af et desillusioneret projekt" (Gane $2000: 39$ )

7. Ifølge referenceværket Vocabulaire de la psychoanalyse kaldes denne betegnelse flere ting på tysk: 'Wunsch', 'Begierde' og 'Lust'. Den betydning, jeg henviser til her, er primært de to sidste. Jeg refererer i resten af min fremstilling af det Freuds begærsteori til (Laplanche/Potalis 1967 /2007). 9. Jeg vil mene, det er det, som Baudrillard prøver med sin eksperimenterende 'Cool memoires'. Her er der primært tale om en stilistisk leg, der ikke udformer klare ideer eller synspunkter, men derimod er der tale om en konstant forskydning af mening. Dermed bliver den fragmentariske stil en illustration af illusionen om betydning og en måde at blive en aktiv deltage i 'den postmoderne tilstand'. 10. Se Foucault 1978.

11. Jeg vil lige præcisere, hvad jeg mener med de forskellige termer: 'performativer' (de grammatiske talehandlinger à la "Jeg erklærer Jer hermed for...”), 'performance' (enkelt stående episoder af optrædener: kønnet performance, gadeteater, politisk aktion etc.) og 'performativitet' (det generelle fænomen at udføre talehandlinger eller 'performance' og teorien herom).

12. (Austin 1962/ 1975: 6)

13. Derridas læsning af Austin fremlægges i artiklen Signature évènement contexte, der forefindes i artikelsamlingen Marges - de la philosophie (1971). Amy Hollywood giver en spændende og nuanceret analyse af forholdet mellem 'performance', magt og gentagelse hos Austin, Derrida og Butler i artiklen Performativity, citationality, ritualization (Hollywood: 2002).

14. Dette er det originale ved Derridas performativitetsteori. Men denne måde at fortolke begrebet på er der ikke enighed om, særligt den amerikanske lingvist John Searle (f.1932) har i bogen Glyph (1977) rettet et angreb mod Derridas dekonstruktivistiske læsning af Austin (Windell 2004: 11). 15. Butler læner sig her igen op af Derrida, som i bogen citeres for at konstatere, at der ikke findes natur, der findes kun naturaliserings- og denaturaliseringsprocesser (Butler 1993: 1).

16. "Amerika er hverken drøm eller virkelighed, det er en hyperrealitet. Det er en hyperrealitet fordi, det er en utopi, som fra starten har udlevet sig selv. Her er alt virkeligt og pragmatisk, og De får lov at drømme. Det kan være, at Amerikas virkelighed kun kan blive synligt for en europæer, fordi han her kan finde det perfekte simulakrum... Det, man skal gøre, er at gå ind i Amerikas fiktion, ind i Amerika som fiktion." (Baudrillard 1986: 57 -59) 18. Ørums fremstilling er meget interessant, da den fremsætter en række af de forhold, som bliver centrale hos Butler, men Ørum gør det uden henvisning til Gender Trouble, der ellers var udkommet på dette tidspunkt: "Hvis kønsforskellen, som postmodernismen hævder det, hviler på sproglige og kulturelle konstruktioner, som stadig skrider under fødderne på os, hvordan kan man så i det hele taget tale om 'kvinders særlige erfaringer', eller i det hele taget definere begrebet 'kvinde'? Og hvordan kan feminister så hævde at tale kvindens sag?" (Ørum/Svane 1991: 23). Dette er naturligvis med til understrege, at queerteoriens hypoteser ligesom lå i luften i den postmodernistiske periode, inden de blev formuleret af Judith Butler.

19. Se ogsa Feminism and the Power of Dissolution (Grace 2000: 172 -192)

20. I kapitlet Reglens lidenskab modstiller Baudrillard loven, der er baseret på forestillingen om sandhed og værdier, og reglen, der er en kæde af tilfældige tegn styret af forskydning og kreativitet: "Det, der står i modsætning til loven, er således slet ikke lovens fravær, men Reglen." (Baudrillard 1979/1997: 137)

21. Dogmebrødrene var en gruppe filminstruktører, der anført af Lars von Trier, lavede et kyskhedsløfte i 1995, se http://www.dogme95.dk

\section{LITTERATUR}

- Austin, John L. (1962/1975): How to do things with words. Clarendon Press, Oxford.

- Baudrillard, Jean (1979/1997): Forforelse - essay om begar og spil, skin og simulation, Det lille forlag, (forord, noter og revideret oversættelse ved Frans Storr-Hansen), København

- Baudrillard, Jean (1981): Simulacres et simulation. Galilée, Paris.

- Baudrillard, Jean (1986): Amérique. Editions grasset \& Fasquelle, Paris. 
- Best, Steven \& Keller, Douglas (1991): Postmodern theory - crucial interrogations. Macmillian, London.

- Butler, Judith (1990/1999): Gender TroubleFeminism and the Subversion of Identity. Routledge, New York.

- Butler, Judith (1993) Bodies that matter - on the discursive limits of "sex", Judith Butler, Routledge, New York.

- Butler, Rex (1999): Jean Baudrillard - the defence of the real. Thousand Oaks, London.

- Carlson, Marvin (2004): Performance - A Critical Introduction. Routledge, (2 $2^{\text {nd }}$ edition $), \mathrm{New}$ York.

. Colebrook, Claire (2004): Gender. Pulgrave Macmillan, 2004, New York.

- Cusset, François (2002): Queer critics - La littérature française déshabillée par ses homo-lecteurs.

Presses Universitaires de France, Paris.

- Foucault, Michel(1978): Herculine Barbin dite Alexina B. Gallimard, 1978, Paris.

- Gane, Mike (2000): Jean Baudrillard - in Radical Uncertainty, Pluto press, New York.

- Goshorn, A. Keith (2000): Valorizing "The Feminine" While Rejecting The Feminism, Baudril- lard's Feminist Provocations, in Gane, Mike (red.) Jean Baudrillard - Sage Masters of Modern social thought, Sage publications, Volume III s. 280 312. London.

- Grace, Victoria (2000): Jean Baudrillard - A feminist reading. Routledge, New York.

- Halperin, David (1993): The Normalizing of Queer Theory, in Journal of homosexuality, V 45, s. 339-343.

. Hollywood, Amy (2002): Performativity, Citationality, Ritualization, History of religions, volume 42, nr. 2, $93-115$, Chicago.

- Laplanche, Jean og J.-B. Potalis $(1967 / 2007)$ artikler i Vocabulaire de la psychoanalyse. Presses Universitaires de France, Paris.

· Rösing, Lillian Munk (2005): Kønnets katekismus. Roskildes Universitetsforlag, Frederiksberg. - Windell, Peter (red.) (2004) Socialkonstruktivismen under debat - om relativisme og realisme $i$ kulturvidenskaberne, Forlaget modtryk, Århus.

- Ørum, Tania \& Svane, Marie-Louise (red.) (1991): Køn og Moderne tider, Tiderne Skifter

Jonatan Leer, mag. art. (fransk/litteraturvidenskab) 